\title{
Gangguan Kepribadian Narsistik dan Implikasinya Terhadap Kesehatan Mental
}

\author{
Dewi Purnama Sari \\ Institut Agama Islam Negeri (IAIN) Curup \\ dewipurnamasari@iaincurup.ac.id
}

\begin{abstract}
On the one hand, the development of social media can provide convenience to the community, both in communication, in developing science and in the economic aspect. But on the other hand, the development of social media also has a negative impact on society. One of the negative impacts of using social media is that it can cause personality disorders, give birth to narcissistic attitudes and behaviors and can interfere with mental health. This study aims to describe the narcissistic personality disorder, the symptoms of a person experiencing narcissistic personality disorder, efforts to overcome narcissistic personality disorder and the relationship between narcissistic personality and mental health. The method used is a research library. The data collection technique used document study, then analyzed using content analysis. The results of the discussion show that narcissistic personality disorder is basically a personality disorder caused by a person's excessive attitude or behavior in seeing himself. If the narcissistic personality causes disruption of life functions, it will have the potential to disrupt mental health.
\end{abstract}

Keywords: Personality Disorder; Narcissistic; Mental Health

\begin{abstract}
Abstrak
Perkembangan media sosial di satu sisi dapat memberikan kemudahan pada masyarakat, baik dalam berkonunikasi, pengembangan ilmu pengetahuan maupun dalam aspek ekonomi. Namun di sisi lain, perkembangan media sosial juga memiliki dampak negatif bagi masyarakat. Salah satu dari dampak negatif penggunaan media sosial diantaranya dapat mengakibatkan gangguan kepribadian, melahirkan sikap dan perilaku narsistik serta
\end{abstract}


dapat menganggu kesehatan mental. Penelitian ini bertujuan untuk menguraikan tentang gangguan kepribadian narsistik, gejala-gejala seseorang mengalami gangguan kepribadian narsistik, upaya untuk mengatasi gangguan kepribadian narsistik dan keterkaitan kepribadian narsistik dengan kesehatan mental. Metode yang digunakan adalah library research. Teknik pengumpulan data menggunakan studi dokumen, kemudian dianalisis dengan menggunakan analisis isi. Hasil pembahasan menunjukkan bahwa gangguan kepribadian narsistik pada dasarnya adalah gangguan kepribadian yang disebabkan adanya sikap atau perilaku seseorang yang berlebihan dalam memandang dirinya sendiri. Jika kepribadian narsistik menyebabkan terganggunya fungsi-fungsi kehidupan, maka akan berpotensi menganggu kesehatan mental.

Kata Kunci: Gangguan Kepribadian; Narsistik; Kesehatan Mental

\section{Pendahuluan}

Beberapa tahun terakhir ini, perkembangan media sosial semakin pesat. Mulai dari facebook, twitter, whatsapp, instragram, chat, dan sebagainya. Di suatu sisi media sosial dapat memberi kemudahan dan menimbulkan dampak positif bagi kehidupan manusia. ${ }^{1}$ Setiap individu dapat berinteraksi dan berkomunikasi dengan mudah dan cepat, serta dapat menjalin hubungan pertemanan dengan individu lain dari daerah maupun negara lain. Individu juga dapat memanfaatkan media sosial untuk berbagi ilmu pengetahuan, pengalaman, bahkan mempromosikan hasil kerajinan yang dapat dijual melalui media online. ${ }^{2}$ Namun di sisi lain, perkembangan media sosial dapat menimbulkan dampak negatif bagi kehidupan manusia, salah satu diantaranya adalah dapat memicu munculnya perilaku narsis. $^{3}$

Perilaku narsis menjadi fenomena yang cukup banyak melanda kalangan masyarakat saat ini. ${ }^{4}$ Kecenderungan perilaku ini semakin sering dijumpai dalam kehidupan sehari-hari di media sosial. Salah satu aktivitas yang sering dilakukan adalah selfie atau memotret diri sendiri, kemudian mengunggahnya ke media

${ }^{1}$ Cahyono, A. S. (2016). Pengaruh media sosial terhadap perubahan sosial masyarakat di Indonesia. Jurnal Publiciana, 9(1), 140-157.

${ }^{2}$ Rachman, A. (2017). Pemanfaatan media sosial bagi penciptaan, pemeliharaan dan penyebarluasan pengetahuan dan keterampilan kearifan lokal di afrika timur. ORASI: Jurnal Dakwah dan Komunikasi, 6(1).

${ }^{3}$ Rahman, T. G., \& Ilyas, A. (2019). Perilaku Narsistik Pengguna Media Sosial di Kalangan Mahasiswa dan Implikasi dalam Layanan Bimbingan Dan Konseling. E-Journal Pembelajaran Inovasi, Jurnal Ilmiah Pendidikan Dasar, 7(4), 1-8.

${ }_{4}$ Rahman, T. G., \& Ilyas, A. (2019). Perilaku Narsistik Pengguna Media Sosial di Kalangan Mahasiswa dan Implikasi dalam Layanan Bimbingan Dan Konseling. E-Journal Pembelajaran Inovasi, Jurnal Ilmiah Pendidikan Dasar, 7(4), 1-8. 
sosial. ${ }^{5}$ Posting update status, memperbaharui profil informasi, serta mengomentari status seseorang seolah sudah menjadi bagian dari gaya hidup individu masa kini. ${ }^{6}$ Media sosial juga sering digunakan untuk mengupload aktivitas keseharian bahkan video yang bersifat pribadi diumbar tanpa malu-malu. Segala hal yang dulu dianggap tabu dan risih, sekarang seolah-olah tidak masalah jika diperlihatkan ke seluruh dunia. ${ }^{7}$

Pesatnya pengguna media sosial seperti facebook dan twitter dikalangan masyarakat, dapat memicu munculnya fenomena sosial berupa "krisis identitas". Hasil penelitian yang dikemukakan Baroness Greenfield, menunjukkan bahwa penggunaan Facebook dan twitter telah melahirkan genarasi baru, yaitu generasi yang terobsesi dengan dirinya sendiri. ${ }^{9}$ Individu memiliki keinginan yang kuat untuk diperhatikan secara terus menerus, seperti keingian bayi untuk mendapatkan perhatian dari ibunya. ${ }^{10}$ Lebih lanjut Greenfield menjelaskan, penggunaan facebook dan twitter secara berlebihan dapat berdampak pada otak manusia atau rewirre the brain, seperti berkurangnya kemampuan berkosentrasi, ingin mendapatkan gratifikasi dan pada gilirannya dapat memicu kehilangan identitas. ${ }^{11}$ Generasi yang terobsesi dengan dirinya sendiri maka akan mendorong muncul sikap selfistis. ${ }^{12}$ Sikap selfistik atau selfi secara berlebihan merupakan salah satu indikator individu mengalami gangguan keperibadian narsistik. $^{13}$

Selfistis adalah istilah untuk menggambarkan seseorang yang memiliki ego ingin melakukan selfie secara berlebihan. Selfistis dinyatakan sebagai gangguan kepribadian, jika perilaku tersebut sudah menganggu funsi-fungsi kehidupan sehar-hari. ${ }^{14}$ Misalnya karena sibuk memfoto diri, pendidikan, pekerjaan dan

${ }^{5}$ Engkus, E., Hikmat, H., \& Saminnurahmat, K. (2017). Perilaku narsis pada media sosial di kalangan remaja dan upaya penanggulangannya. Jurnal Penelitian Komunikasi, 20(2).

${ }^{6}$ Widiyanti, E., \& Herwandito, S. (2018). Identitas diri dan hiperealitas dalam media sosial. Cakrawala, 7(2), 231-250.

7 Abadi, T. W., Sukmawan, F., \& Utari, D. A. (2016). Media sosial dan pengembangan hubungan interpersonal remaja di Sidoarjo. KANAL: Jurnal Ilmu Komunikasi, 2(1), 95-106.

${ }^{8}$ Hidayah, N., \& Huriati, H. (2017). Krisis identitas diri pada remaja "identity crisis of adolescences". Sulesana: Jurnal Wawasan Keislaman, 10(1), 49-62.

${ }^{9}$ Nurmalasari, Y. (2016). Konseling Singkat Berfokus Solusi dalam Mengembangkan Kemampuan Mengendalikan Compulsive Internet Use Siswa. EMPATI-Jurnal Bimbingan dan Konseling, 3(2).

${ }^{10}$ Holilah, I. (2017). Dampak Media Terhadap Perilaku Masyarakat. Jurnal Studi Gender dan Anak, 3(01), 103-114.

${ }^{11}$ Najamuddin, N., Negara, H. R. P., Ramdhani, D., \& Nurman, M. (2019). Sosial Media Dan Prestasi Belajar: Studi Hubungan Penggunaan Facebook Terhadap Prestasi Belajar Siswa. Jurnal Tatsqif, 17(1), 70-86.

${ }^{12}$ Hendrata, N. D., \& Christianto, L. P. (2017). Keterkaitan Minat Selfie Dengan Kepribadian Narsistik dan Harga Diri Pada Remaja.

${ }^{13}$ Husni, M. (2019). Selfie Gangguan Kepribadian Narsistik. Jurnal Tinta, 1(1), 105-116.

${ }^{14}$ Hendrata, N. D., \& Christianto, L. P. (2017). Keterkaitan Minat Selfie Dengan Kepribadian Narsistik dan Harga Diri Pada Remaja. 
aktivitas kehidupan sehari-hari terganggu. Dalam kajian psikologi, jika sikap atau perilaku sudah melewati batas normal sampai mengganggu fungsi kehidupan, maka akanmengakibatkan pada seseorang mengalami distress. ${ }^{15}$ Misalnya sebuah kasus yang pernah terjadi di Inggris, remaja 19 tahun mencoba bunuh diri karena foto selfienya dianggap tidak sempurna. ${ }^{16}$

Gangguan kepribadian adalah perilaku maladaptif yang berlangsung lama. ${ }^{17}$ Individu yang mengalami gangguan kepribadian biasanya mudah stress dan mengalami kesulitan dalam memecahkan masalah. ${ }^{18}$ Gangguan ini seringkali ditemukan pada remaja awal dan mungkin berlangsung terus pada kehidupan dewasa. ${ }^{19}$ Orang yang mengalami gangguan kepribadian seringkali tidak merasa terganggu dan tidak memiliki motivasi untuk merubah sikap dan perilakunya, mudah kehilangan kontak dalam realitas sosial dan tidak menunjukkan perilaku yang terorganisir. ${ }^{20}$

Gangguan kepribadian merupakan gangguan yang bersifat kompleks. ${ }^{21}$ Gangguan keperibadian bukan hanya menyangkut pola perilaku, melainkan juga meliputi pengalaman internal individu yang sudah bertahan lama, bersifat pervasif, kaku dan tidak sejalan dengan ekspektasi budaya serta dapat menganggu hubungan sosial dan pekerjaan. Di sisi lain, gangguan kepribadian dapat menyebabkan strees secara emosional. ${ }^{22}$ Menurut Frederick H Kanfer dan Arnold P Goldstein, seseorang yang mengalami gangguan kepribadian akan mengalami kesulitan dalam berinteraksi dengan orang lain. ${ }^{23}$ Kesulitan tersebut timbul akibat adanya persepsi tentang kehidupan dan sikapnya terhadap diri sendiri. Orang yang mengalami gangguan kepribadian dalam dirinya sering kali timbul perasaan cemas, tegang, berlebihan dalam menyikap masalah yang dihadapi dan selalu merasa tidak puas secara berlebihan. Gejala tersebut terkadang tidak disadari, namun dirasakan oleh orang di sekitarnya. ${ }^{24}$

${ }^{15}$ Asrori, A. (2016). Terapi kognitif perilaku untuk mengatasi gangguan kecemasan sosial. Jurnal Ilmiah Psikologi Terapan, 3(1), 89-107.

${ }^{16}$ Insani, C. Kajian psikologi komunikasi pada fenomena selfie remaja di facebook. Relasi negara industri dan masyarakat dalam perspek.tif komunikasi, 217.

${ }^{17}$ Husni, M. (2019). Selfie Gangguan Kepribadian Narsistik. Jurnal Tinta, 1(1), 105-116.

18Zahnia, S., \& Sumekar, D. W. (2016). Kajian epidemiologis skizofrenia. Jurnal Majority, 5(4), 160-166.

${ }^{19}$ Atkinson, Rita L., (1991), Pengantar Psikologi Jilid 2, Batam : Ineraksa, h. 467

${ }^{20}$ Ibid.

${ }^{21}$ Mujib, A. (2017). Teori kepribadian perspektif psikologi Islam.

22 Davidson, Gerald C., (2010), Psikologi Abnormal, Jakarta : Rajagrafindo Persada, h. 574575

${ }^{23}$ Mansir, F. (2018). Pendekatan Psikologi dalam Kajian Pendidikan Islam. Psikis: Jurnal Psikologi Islami, 4(1), 61-73.

${ }^{24}$ Djamaludin Ancok, (2011), Psikologi Islami Solusi Islam atas Problem-problem Psikologi, Yokyakarta : Pustaka Pelajar, h. 91 
Gangguan kepribadian narsistik atau disebut juga dengan istilah narcissistic personality disorder terjadi akibat adanya sikap atau perilaku seseorang yang secara berlebihan dalam memandang keunikan atau kelebihan yang dimiliki, sehingga menimbulkan fantasi yang berlebihan terhadap dirinya sendiri. ${ }^{25}$ Individu yang mengalami gangguan kepribadian narsistik selalu mengharapkan perhatian dan pemujaan yang berlebihan terhadap dirinya, suka memperlihatkan kelebihan yang dimuliki secara berlebihan serta menganggap sikap dan perilakunya hanya dapat dimengerti serta dipahami oleh orang-orang tertentu. Akibatnya adalah melahirkan sikap yang kurang empati terhadap orang lain, arogan, iri, ingin diperlakukan secara istimewa oleh orang lain, selalu mencari perhatian, ingin dipuja, takut gagal, sensitif terhadap keritikan. ${ }^{26}$ Orang yang mengalami gangguan kepribadian narsistik terkadang sering merasa kecewa terhadap dirinya, lalu mencari orang-orang yang dianggapnya ideal dengan tidak mengizinkan orang lain menjalin hubungan. Jika ada orang lain dianggap mampu menyainginya, ia akan marah dan berupaya menyingkirkannya. ${ }^{27}$

Narsistik pada gilirannya akan memicu sikap riya. Riya adalah sikap seseorang yang suka memperlihatkan atau menampakkan amal saleh karena ingin dilihat dan didengar oleh orang lain disebut riya. Firman Allah dalam QS An-Nisa ayat 142 :

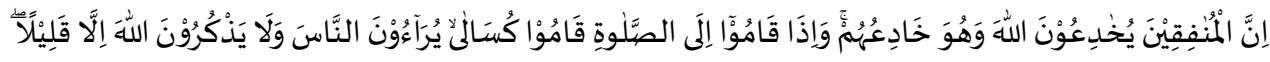

Sesungguhnya orang munafik itu hendak menipu Allah, tetapi Allab-lah yang menipu mereka. Apabila mereka berdiri untuk salat, mereka lakukan dengan malas. Mereka bermaksud ria (ingin dipuji) di hadapan manusia. Dan mereka tidak mengingat Allah kecuali sedikit sekali.(QS. An-Nisa: 142)

Maksud riya dalam ayat di atas adalah melakukan sesuatu karena pamrih ingin dilihat dan dipuji di hadapan manusia. ${ }^{28}$ Menurut al-Muhasibi ada tiga faktor yang membangkitkan sifat riya, yaitu : senang dipuji, takut dicela dan dihina, serta tamak pada dunia dan kekayaan. ${ }^{29}$ Lebih lanjut al-Muhasibi menjelaskan, sifat riya juga dapat menjerumuskan manusia pada kemusyrikan. Walaupun secara lahiriah dia menampakkan menyembah Allah SWT, namun secara batiniah dia tidak menyembah Allah SWT. ${ }^{30}$ Akibat yang ditimbulkan oleh sifat riya adalah merasa sombong dan bangga diri. Rasa sombong dan bangga diri ini disertai dengan rasa tidak senang jika melihat orang lain berada di atas

\footnotetext{
${ }^{25}$ Suhartanti, L. (2016). Pengaruh kontrol diri terhadap narcissistic personality disorder pada pengguna Instagram di SMA N 1 Seyegan. E-Journal Bimbingan dan Konseling, 8(5), 184-195.

${ }^{26}$ Jazilah, N. (2017). Hubungan antara kesepian dengan ciri-ciri narsistik pada pelaku selfie di media sosial. Naskah Publikasi Prodi Psikologi.

${ }^{27}$ Davidson, Gerald C., (2010), Psikologi Abnormal, h. 586

${ }^{28}$ Quraish Shihab (2007), Tafsir Al-Misbah Vol. 2, Jakarta : Lentera Hati, h. 144

${ }^{29}$ Sahri, M. A. (2021). Mutiara akblak tasawnf. PT. Raja Grafindo Persada.

${ }^{30}$ Ibid.,
} 
dirinya. Berlomba-lomba untuk mendapatkan harta dan urusan keduniawian, bahkan sampai menolak kebenaran dari orang lain. ${ }^{31}$

Berapa pendapat di atas dapat dipahami bahwa orang dengan gangguan kepribadian narsistik memandang dirinya dengan cara berlebihan, senang sekali menyombongkan diri, dan berharap orang lain memberikan pujian. Enggan atau tidak bisa menerima kritikan orang lain, tetapi sebaliknya malah suka mengkritik orang lain. Orang dengan gangguan kepribadian narsistik suka menilai tinggi dirinya sendiri, melebih-lebihkan kemampuannya, keasyikan dengan menjadi dikagumi, dan kurangnya empati terhadap perasaan orang lain. Dalam al-Quran, sifat-sifat yang dimiliki oleh orang dengan gangguan kepribadian narsistik sangat jauh dari rasa malu. Padahal Rasulullah SAW menempatkan rasa malu dalam kedudukan yang tinggi dalam syariat Islam. Akibat mengabaikan rasa malu, orang dapat menghancurkan kehidupannya. Rasulullah SAW bersabda, "Sesungguhnya setiap agama memiliki akhlak, dan akhlak Islam adalah malu." (Riwayat Ibnu Majah). Rasulullah SAW tidak menyukai orang yang tidak memiliki rasa malu, "Jika kamu tidak malu berbuatlah sesukamu." (Riwayat Abu Dawud). Dan Rasulullah SAW sendiri adalah seorang yang sangat pemalu, "Sifat malu Rasulullah SAW lebih besar daripada gadis yang ada di dalam kamar pingitannya. Apabila beliau tidak menyukai sesuatu maka hal itu dapat diketahui dari raut muka beliau." (Riwayat Anas bin Malik). ${ }^{32}$

Haya binti Mubarok Al-Barik mengelompokkan sifat sombong (takabbur), ingin dipuji orang (riya), gila ketenaran (bubbul jab), serta tergila-gila dengan dunia (bubbuddunya) termasuk sifat-sifat yang tercela. ${ }^{33}$ Sifat-sifat tercela adalah sifat yang harus dihindari. Salah satu berkah yang didapat dari rasa malu adalah membuat individu terbiasa berperilaku terpuji dan menjauhi perilaku tercela. Muncul pertanyaan, apakah gangguan kepribadian itu? Apa pula yang disebut dengan gangguan kepribadian narsistik? Apakah gejala-gejala yang dapat dijadikan indikator bahwa seseorang mengalami gangguan kepribadian narsistik? Upaya apa saja yang dapat dilakukan untuk mengatasi gangguan kepribadian narsistik? Apakah gangguan kepribadian narsistik merupakan salah satu bentuk gangguan jiwa yang dapat mempengaruhi kesehatan mental?

Artikel ini bertujuan untuk membahas dan menguraikan beberapa pertanyaan tersebut dengan menggunakan metode library research. Library research merupakan salah satu jenis penelitian dimana dalam menjawab masalah penelitian dilakukan dengan mengumpulkan berbagai informasi, teori dan kajian yang berumber dari buku, artikel ilmiah dan hasil penelitian. ${ }^{34}$ Prosdur

\footnotetext{
${ }^{31}$ Rosleni Marliany (2015), Psikologi Islam, Bandung : Pustaka Setia, h. 159

32 Imam Abu Syaikh, (2011), Meneladani Akblak Nabi, Jakarta : QitshiPress, h. 29

${ }^{33}$ Haya Binti Mubarok Al-Barik (1418 H), Ensiklopedi Wanita Muslimah, Jakarta : Darul Falah, h. 125

34 Zed, M. (2004). Metode peneletian kepustakaan. Yayasan Obor Indonesia.
} 
penelitian dilakukan dengan beberapa langkah, yaitu penentuan topik, menentukan fokus penelitian, mengumpulkan sumber, penyajian dan analisis data. ${ }^{35}$ Teknik pengumpulan daya yang digunakan adalah studi dokumen dan dianalisis dengan analisis isi atau content analysis. ${ }^{36}$

\section{HASIL DAN PEMBAHASAN}

\section{Gangguan Kepribadian Narsistik}

\section{Pengertian dan ciri-ciri gangguan kepribadian narsistik}

Kata narsistik merupakan turunan dari kata narsisme. Kata narsisme diambil dari nama pemuda tampan yang bernama Narcissus pada zaman Yunani Kuno. ${ }^{37}$ Narcissus sangat kagum terhadap dirinya sendiri setelah melihat bayangbayang wajahnya di permukaan air tenang dalam hutan. Dalam kehidupannya, Narcissus selalu berupaya menjalin hubungan dengan seseorang namun selalu gagal karena belum ada yang dikagumi melebihi dari dirinya. Akhirnya ia putus asa dan bunuh diri karena tidak bisa memenuhi keinginanya untuk menjalin cinta dengan orang yang memiliki kelebihan dirinya. ${ }^{38}$ Penjelasan tersebut, menggambarkan bahwa jika seseorang idnividu mengagumi dirinya sendiri secara belebihan dan menganggap dirinya paling ideal, maka akan mengalami kesulitan dalam menjalin hubungan dengan orang lain.Orang yang mengalami gangguan kepribadian, sering kali tidak merasakan jika dirinya mengalami gangguan, namun orang disekitarnya dapat merasakannya. ${ }^{39} \mathrm{Ciri}$ lain orang yang mengalami gangguan kepribadian adalah memiliki kepribadian yang tidak wajar, tidak dewasa, sukar menyesuaikan diri, sering strees dalam memecahkan masalah yang dihadapinya. ${ }^{40}$

Secara bahasa narsistik merupakan perasaan cinta terhadap diri sendiri yang berlebihan. ${ }^{41}$ Gangguan kepribadian narsistik termasuk gangguan mental yang disebabkan adanya perasaan ego yang tinggi dan kekaguman yang berlebihan terhadap dirinya sendiri. ${ }^{42}$ Individu yang mengalami gangguan kepribadian

35 Khatibah, K. (2011). Penelitian kepustakaan. Iqra': Jurnal Perpustakaan dan Informasi, 5(01), 36-39.

36 Zed, M. (2004). Metode peneletian kepustakaan.

37 Izzati, F., \& Irma, A. (2018). Perilaku Narcissistic Pada Pengguna Instagram Di Kalangan Mahasiswa Universitas Serambi Mekkah. Jurnal Ilmiah Mahasiswa Fakultas Ilmu Sosial \& Ilmu Politik, 3(2).

${ }^{38}$ Engkus, E., Hikmat, H., \& Saminnurahmat, K. (2017). Perilaku narsis pada media sosial di kalangan remaja dan upaya penanggulangannya. Jurnal Penelitian Komunikasi, 20(2).

${ }^{39}$ Davidson, Gerald C (1010), Psikologi Abnormal, Jakarta : Rajagrafindo Persada, h. 575

${ }^{40}$ Ibid.

${ }^{41}$ Widiyanti, W., Solehuddin, M., \& Saomah, A. (2017). Profil perilaku narsisme remaja serta implikasinya bagi bimbingan dan konseling. Indonesian Journal of Educational Counseling, 1(1), $15-26$.

${ }^{42}$ Davidson, Gerald C., Op. Cit., h. 576 
narsistik sering kali memandang dirinya lebih baik dari orang lain, memiliki fantasi yang berlebihan terhadap keberhasilan yang dicapainya dan kurang memperhatikan perasaan orang lain. ${ }^{43}$

Di lihat dari sejarahnya, istilah gangguan kepribadian narsistik muncul dalam teori psikoanalisis modern. ${ }^{44}$ Ahli psikoanalisis berasumsi bahwa gangguan kepribadian narsistik merupakan produk dari sistem nilai masa kini. ${ }^{45}$ Teori narsisme di era kontemporer banyak dikembangkan oleh Heinz Kohut melalui dua bukunya, The Analysis of the Self (1971) dan The Restoration of the Self (1977), pada perkembangan selanjutnya teori tersebut dikenal dengan teori selfpsychology. ${ }^{46}$ Kohut menjelaskan, gangguan kepribadian narsistik terjadi akibat adanya kegagalan dalam mengembangkan harga diri yang sehat. Hal ini disebabkan oleh ketidakmampuan orang tua dalam merespon secara baik berbegai kompetensi yang dimiliki oleh anaknya, anak seringkali dihargai guna untuk membangun kebanggaan dan harga diri orang tua, bukan berdasarkan makna dirinya sendiri. ${ }^{47}$

Beberapa ciri gangguan kepribadian narsisistik antara lain cinta secara berlebihan terhadap diri sendiri, meganggap dirinya memiliki kelebihan yang unik, diringi dengan keinginan untuk mengagungkannya, selalu ingin mencari perhatian dan pujian dari orang lain, ingin mendapatkan perlakukan spesial, kurang peka terhadap kebutuhan orang lain dan memiliki khayalan yang berlebihan terhadap dirinya walaupu dalam pandangan orang lain biasa-biasa saja. ${ }^{48}$ Dalam DSM-IV (Diagnostic and Statistical Manual of Mental Disorders-Fourth Edition) seseorang dikatakan mengalami gangguan kepribadian narsistik jika memiliki lima dari sembilan ciri, yaitu merasa paling hebat, seringkali memiliki perasa iri hati kepada orang lain, memiliki fantasi secara berlebihan terhadap kesukesan dan kelebihannya, ingin dikagumi secara berlebihan, kurang memiliki empati terhadap orang lain, selalui ingin memperoleh keistimewaan, memiliki sikap angkuh, sensitif terhadap kritik, memiliki kepercayaan diri secara semu,

${ }^{43}$ Engkus, E., Hikmat, H., \& Saminnurahmat, K. (2017). Perilaku narsis pada media sosial di kalangan remaja dan upaya penanggulangannya. Jurnal Penelitian Komunikasi, 20(2).

${ }^{44}$ Santi, N. N. (2017). Dampak kecenderungan narsiscisme terhadap self esteem pada pengguna facebook mahasiswa PGSD UNP. Jurnal Dimensi Pendidikan dan Pembelajaran, 5(1), 2530.

${ }^{45}$ Syam, E., Fauzi, M., \& Syamsidari, R. (2017). Narsisisme dan kompleks oedipus yang tergambar dalam Pygmalion, karya George, Bernard Shaw: Kajian Psikoanalisis . Jurnal Pustaka Budaya, 4(2), 58-82.

${ }^{46}$ Azizurahman, M. A. M., \& Purnama, H. (2017). Representasi Narsisme Dalam Iklan Sprite (analisis Semiotika Charles Sanders Peirce Pada Iklan Youtube Sprite Versi Kenyataan Gak Seindah Sosmed Selebriti-\# ootd). eProceedings of Management, 4(3).

${ }^{47}$ Ibid., h. 587

${ }^{48}$ Fausiah \& Widury, J(2005), Psikologi Abnormal: Klinis Dewasa,Jakarta : Universitas Indonesia, h. 92 
memiliki keyakinan secara berlebihan bahwa dirinya memiliki keunikan dan hanya dapat dimengerti oleh orang-orang tertentu. ${ }^{49}$

\section{Faktor penyebab munculnya keperibadian narsistik}

Banyak faktor yang memyebabkan munculnya gangguan kepribadian narsistik. Kohut $(1971,1977)$ berbendapat, gangguan kepribadian narsistik terjadi akibat kegagalan anak dalam neniru empati dari orang tua khususnya pada pada masa perkembagan awal akan-anak, anak terfiksasi pada tahap perkembangan berikutnya. ${ }^{50}$ Akibatnya, setelah dewasa belum menemukan hasil dalam mencari figur ideal untuk memenuhi kebutuhan empatinya. ${ }^{51}$ Menurut teori psikodinamik, individu akan terhindar dari gangguan keribadian narsistik jika padamasa akan-akan mampu menjalani fase perkembangan secara normal. ${ }^{52}$ Oleh karena itu, orang tua harus mampu mengembangkan tingkat kepercayaan diri secara normal dan mengembangkan perasaan harga diri anak secara benar.

Kohut dan Kernberg menjelaskan, kepribadian narsistik akan berkembang dalam diri individu, jika orang tua lalai terhadap anak, kurang berempetai dan selalu menghilangkan nilai terhadap apa yang dilakukan oleh anak. Bila hal ini terjadi, anak akan mencari sendiri dengan cara mengidealkan dirinya sendiri. ${ }^{53}$ Munculnya kelainan kepribadian narsistik terjadi akibat adanya penilaian secara berlebihan terhadap realitas yang dialami oleh anak. ${ }^{54}$ Sikap orang tua memanjakan dan menuruti segala permintaan anak-anaknya merupakan salah satu contoh sikap yang berlebihan terhadap realitas yang dialami oleh anak. ${ }^{55}$

Ahli lain menyatakan trauma masa kanak-kanak merupakan salah satu faktor utama menjadi penyebab munculnya narsis. Bahkan Sigmond Freud berkeyakinan bahwa perilaku narsis muncul dari kombinasi pujian orang tua dan penolakan. Memanjakan anak berlebihandan pengabaian orang tua terhadap anak merupakan pemicu munculnya gangguan keperibadian narsistik. ${ }^{56}$

\footnotetext{
${ }^{49}$ Saleh, G., \& Muzammil, M. Pengaruh media sosial instagram dalam perilaku narsis pada pelajar SMA di kota Pekanbaru. Jurnal Ilmu Komunikasi, 8(4).

50James and Butcher, Susan Mineka, Jill M (2008), Abnormal Psychology Core Concept, Hooley: Pearson Educational USA, h. 241

${ }^{51} \mathrm{Ibid}$.

${ }^{52}$ Haryanto, H., Wahyuni, H. D., \& Nandiroh, S. (2016). Sistem Deteksi Gangguan Depresi Pada Anak-anak dan Remaja. Jurnal Ilmiah Teknik Industri, 14(2), 142-152.

${ }^{53}$ Engkus, E. (2016). Perilaku narsis di kalangan remaja pelajar pada media sosial dan upaya penanggunglangannya (penelitian terhadap ramaja pelajar di kawasan Bandung Timur). lib. uinsgd. ac. id, 1-150.

54 Triwahyuni, A., Purwono, U., Sadarjoen, S. S., \& Sapri, E. R. (2019). Pengembangan Millon Personality Type Inventory (MPTI) sebagai Instrumen Pengukuran Kepribadian di Indonesia. Journal of Psychological Science and Profession, 3(2), 65-74.

${ }^{55}$ Ibid.

${ }^{56}$ Husni, M. (2019). Selfie Gangguan Kepribadian Narsistik. Jurnal Tinta, 1(1), 105-116.
} 


\section{Upaya Penanganangangguan kepribadian narsistik}

Ada beberapa cara yang dapat dilakukan untuk menanganai gangguan kepribadian narsistik. Salah satu diantaranya adalah dengan melatih diri agar bisa mengontorol dan mengendalikan motif-motif emosi yang mengarah pada sikap dan perilaku narsistik. ${ }^{57}$ Oleh karena itu perlu dilakukan pengamatan terhadap perilaku individu terhadap orang lain untuk mengetahui motif munculnya perilaku tersebut berasal dari motif narsistik atau bukan. Di sisi lain, dapat dilakukan dengan melatih diri bersiukap empati terhadap orang lain dan membiasakan diri melihat sikap, perilaku serta masalah yang dialami dari sudut pandang orang lain. ${ }^{58}$

Fausiah, F \& Widury menjelaskan bahwa ada beberapa proses yang dapat dilakukan untuk menangani gangguan kepribadian narsistik belum bersifat kronis, yaitu :

a. Melatih diri memandang orang lain secara positif. Dalam kontek ini, individu dilatih agar memilik pendangan dan keyakina bahwa orang lain memiliki kelebihan dan keistimewaan.

b. Selalu mengambil hikmah dan pelajaran dari sikap dan perilaku yang ditampilkan.

c. Bersikap dan berprilaku sederhana secara porposional agar terhindar dari prangkap hedonisme.

d. Melatih diri bersikap rendah hati. Hal ini dapat dilakukan dengan cara belajar dari pengalaman orang lain, membaca buku serta melakukan evaluasi terhadap sikap dan perilaku yang telah dilakukan dalam kehidupan seharihari.

e. Koreksi terhadap ucapan, prilaku dan sikap yang muncul dalam diri yang mengandung kesombongan, hal ini bisa muncul direnungkan. ${ }^{59}$

\section{Kesehatan Mental}

\section{Pengertian kesehatan mental}

Kesehatan mental terdiri dari dua kata, yaitu kesehatan dan mental. Kesehatan asal katanya sehat. Kata kesehatan diambil dari kata hyginene yang berarti ilmu kesehatan. Kata mental dalam bahasa Latin diistilahkan dengan kata mens, mentis yang berarti jiwa, sukma roh semangat. ${ }^{60}$ Secara etimologi kesehatan mental dapat diartikan ilmu tentang kesehatan jiwa.

\footnotetext{
${ }^{57}$ Engkus, E., Hikmat, H., \& Saminnurahmat, K. (2017). Perilaku narsis pada media sosial di kalangan remaja dan upaya penanggulangannya. Jurnal Penelitian Komunikasi, 20(2).

${ }^{58}$ Sakinah, U., Zatrahadi, M. F., \& Darmawati, D. (2019). Fenomena Narsistik di Media Sosial Sebagai Bentuk Pengakuan Diri. Al-Ittizaan: Jurnal Bimbingan Konseling Islam, 2(1), 34-43.

${ }^{59}$ Fausiah, F \& Widury, J, Op. Cit., h. 97-98

${ }^{60}$ Syamsu Yusuf (2004), Mental Hygiene Pengembangan Kesehatan Mental Dalam Kajian Psikologi dan Agama, Bandung: Pustaka Bani Quraisy, h. 7.
} 
Secara terminologi para ahli memberikan definisi berbeda-beda sesuai dengan sudut pandang masing-masing. Dengan adanya perbedaan definisi tersebut, maka sangat sulit untuk menggeneralisasi definisi kesehatan mental yang mampu memberikan pemahaman yang mencakup semua aspek sesuai dengan sudut pandang semua ahli. Kartini Kartono mengistilahkan kesehatan mental dengan istilah mental byginene. Mental bygiene ialah ilmu yang bertujuan untuk memiliki dan membina jiwa yang sehat, mencegah timbulnya kepatahan jiwa atau mental break-down, mencegah berkembangnya berbagai penyakit mental dan sebab musabab timbulnya penyakit tersebut, serta mengusahakan penyembuhan dalam stadium permulaan. Pencegahan munculnya penyakit mental dapat dilakukan dengan melakukan beberapa kegiatan yang bersifat preventif dan kuratif. Kegiatan yang bersifat prefentif bertujuan untuk mencegah, sedangkan kegiatan bersifat kuratif untuk membantu individu yang mengalami gangguan emosi dan mental. ${ }^{61}$ Mesehatan mental sebagai ilmu pengetahuan yang memberikan gambaran tentang dasar-dasar mental yang sehat, sebab-sebab terjadinya gangguan mental, cara mencegah, mengatasi serta memelihara agar individu berada dalam kondisi yang sehat mental dan merasakan kebahagiaan dalam hidupnya. ${ }^{62}$ Kesehatan juga mengkaji cara mencegah, mengurangi dan menyembuhkan berbagai gangguan mental dan emosi agar seseorang memiliki jiwa yang sehat. ${ }^{63}$

Menurut aliran Psikoanalisa kesehatan mental merupakan derajat kekuatan ego atau aku seseorang. Semakin kuat ego seseorang maka akan semakin sehat mentalnya. Paham Behaviorisme mendefinisikan kesehatan mental merupakan ilmu mempelajari kesehatan jiwa atau mental. Mental yang sehat menurut paham Behaviorisme adalah orang-orang yang mampu menyesuaikan diri yang selalu berubah. Sementara menurut alirah Humanisme kesehatan mental merupakan pengembangan potensi-potensi diri sebesar mungkin, terhambatnya perkembangan potensi merupakan suatu penyebab munculnya penyakit. ${ }^{64}$

Rumusan kesehatan mental dikemukakan para ahli di atas cukup luas dan belum mencaku semua aspek kehidupan manusia. Para ahli di atas melum memasukkan unsur agama dalam berbicara kesehatan mental. Agama merupakan unsur terpenting dalam kesehatan mental. Beragama merupakan fitrah manusia. Dengan agama manusia akan memperoleh ketenteraman dan ketenagan jiwa. Ketenangan jiwa merupakan karakteristik utama jiwa yang sehat. Dalam agama terdapat petunjuk dan nilai-nilai yang membawa manusia kepada

\footnotetext{
${ }^{61}$ Kartini Kartono (19998), Mental Hygiene (Kesehatan Mental), Bandung: Alumni, Cet. Ke 5, h. 2

${ }^{62}$ Arif Budiman dan Abu Bakar Baradja (1999), Mental Sehat Hidup Nikmat, Mental Sakit Hidup Pahit, (Jakarta: Studi Press, h. 11

${ }^{63}$ Hasan Langgulung (2000), Teori-teori Kesehatan Mental, Jakarta: al Husna, h. 303

${ }^{64}$ Ibid., h. 2966
} 
ketenteraman jiwa, kesejahteraan dan kebahagiaan hidup di dunia dan di akhirat. Agama memberi petunjuk kepada manusia ke jalan yang terbaik untuk membebaskan diri dari berbagai ganggguan kejiwaan.

Hal inilah sesungguhnya yang selama ini tidak dikaji oleh beberapa psikologi modern (psikologi Barat) sehingga dalam mengkaji manusia tidak secara komprehensip. Menurut Komarudin Hidayat walapun beberapa tokoh psikologi Barat seperti Aport, Abraham Maslow dan lainnya telah meratakan jalan bagi apresiasi spiritualitas keagamaan pada diri manusia, namun mereka berhenti bahkan berbali sehingga tidak mau mengakui adanya suatu bentuk disiplin ilmu keagamaan. ${ }^{65}$

Oleh karena itu, dalam mendefinisikan kesehatan mental perlu merujuk pengertian lain yang memasukkan dimensi agama ke dalam bagian kesehatan mental. Hal ini sebagaimana dikemukakan oleh Zakiyah Daradjat yang menjelaskan bahwa seseorang dikatakan memiliki mental yang sehat, apabila tidak memiliki keluhan dan gangguan mental khususnya dalam kaitannya dengan penyesuaian diri secara sosial atau neurosismaupun psikosis. ${ }^{66}$ Lebih lanjut Daradjat menjelaskan bahwa individu yang memiliki mental yang sehat, maka dalam dirinya ada keserasian antara fungsi-fungsi jiwa, diri dan lingkungannya yang didasari oleh iman dan takwa untuk mendapatkan kehidupan hakikiki yaitu bahagia di dunia dan akhirat. ${ }^{67}$

Beberapa difinisi kesehatan mental sebagaimana dikemukakan di atas setidaknya ada dua pandangan dalam mendefinisikan kesehatan mental, yaitu pertama, kesehatan mental dipandang sebagai sebagai suatu kondisi. Kedua, kesehatan mental sebagai ilmu pengatahuan. Dari sudut pandang kondisi, kesehatan mental merupakan perwujudan dan penyesuaian diri yang baik dalam seluruh aspek kehidupan manusia sehingga tercapai kedamaian dan kesejahteraan hidup. Pada aspek ilmu pengetahuan, kesehatan mental dipandang sebagai ilmu yang terpaut dengan kesejahteraan dan kebahagiaan yang mencakup usaha-usaha pencehagan, pengonbatan serta pembinaan dan peningkatan kondisi kesehatan mental.

\section{Teori-teori Kesehatan Mental}

Berbicata tentang teori kesehatan mental berarti berbicara tentang teori psikologi. Sebab secara empiris, kesehatan mental merupakan salah satu cabang dari ilmu jiwa atau psikologi yang muncul sekitar abad ke-19 dan berkembang

\footnotetext{
${ }^{65}$ Komarudin Hidayat (1998), Agama Masa Depan: Presfektif Filsafat Parennial, Jakarta: Pramadina, h. 86

${ }^{66}$ Zakia Daradjat (2012), Islam dan Kesehatan Mental, Jakarta: PT. Gunung Agung, h. 10-14

${ }^{67}$ Yahya Jaya (1999), Peranan Taubat dan Maaf dalam Kesehatan Mental, Jakarta: Ruhama, h. 
secara pesat sekitar pertengahan abad ke-20. ${ }^{68}$ Dalam membahas terkait dengan teori-teori kesehatan mental ada tiga teori dasar dalam psikologi, yaitu teori psikoanalisa, teori behaviorisme dan teori humanisme. Dari sudut pandang ketiga teori tersebut akan diuraikan konsep dasar tentang kesehatan mental.

a. Teori Psikoanalisa

Teori pskoanalisa dikemukakan oleh Sigmund Freud. ${ }^{69}$ Teori ini pertama kali lahir menangani atau merawat individu yang mengalami sakit mental. ${ }^{70}$ Namun pada akhirnya teori ini berkembang menjadi teori kepribadian atau personality dan juga digunakan sebagai salah satu metode psikoterapi.Sebagai teori keperibadian, teori psikoanalisa membicarakan tentang kehidupan manusia yang meliputi struktur, sifat, hakekat manusai dan lain sebagainya. Menurut Freud keperibadian manusai terdiri dari tiga sistem yang saling berhubungan, yaitu $i d$, ego dan super ego, dalam bahasa Indonesia diterjemahkan menjadi dia, aku dan aku yang agung. ${ }^{71}$ Ketiga aspek ini juga disebut dengan aspek biologis, psikologis dan aspek sosiologis. ${ }^{72}$ Aspek-aspek ini walaupun mempunyai fungsi, sifat, komponen dan prinsip kerja serta dinamika sendiri, namun ketiga saling berhubungan dan tidak bisa memisahkan pengaruhnya terhadap tingkah laku manusia. Tingkah laku manusia merupakan asil kerja sama dari ketiga aspek tersebut (id, ego dan super ego).

Id merupakan aspek psikologis dan sistem yang orisinil dalam keperibadian yang berisikan tentang hal-hal yang dibawa sejak lahir, yang meiputi unsur-insur biologis dan termasuk didalamnya instink. Id merupakan resevoir energi psikis yang berfungsi sebagai penggerak ego dan super ego. Yang menjadi pedoman fungsi id adalah menghindari diri dari ketidakenakan dan mengejar kesenangan, sehingga dalam fungsinya $i d$ berpedoman pada prinsip kesenangan atau the pleasure principle. ${ }^{73}$ Sedangkan sifat $i d$ dalam bertindak bersifat implusif dan tidak berdasarkan akal sehat atau tidak bersifat logis, amoral dan didorong oleh suatu kepentingan, yaitu memuaskan kebutuhan naluriah sesuai dengan asas kesenangan. ${ }^{74}$ Ego tumbuh sebagai kebutuhan akan dunia nyata yang berfungsi sebagai penghubung naluri-naluri dengan lingkungan sekitar. Karena ego berhubungan dengan dunia nyata, prinsip kerjanya perpedoman pada prinsi

${ }^{68}$ Hamid, A. (2017). Agama dan kesehatan mental dalam perspektif psikologi agama. Healtby Tadulako Journal (Jurnal Kesehatan Tadulako), 3(1), 1-14.

${ }^{69}$ Sigmund Freud (1993), Sekelumit Sejarah Psikologianalisa, Terjemahan K. Bertens, Jakarta: Gramedia, h. 3

${ }^{70}$ Robert. W. Crapps (1997), Dialog Psikologi dan Agama Sejak William james bingga Gordont. W. Allpot, Terjemahan Harjana, Yogyakarta: Kanisus, h. 60

${ }^{71}$ Hasan Langgulung, Op. Cit., h. 15

${ }^{72}$ Sumadi Suryabrata (2008), Psikologi Keperibadian, Jakarta: Rajawali Press, h. 145

${ }^{73}$ E. Keswara (19997), Teori-teori Kepribadian, Bandung: Erosco, h. 33

${ }^{74}$ Gerald Corey (1999), Tori dan Praktek Konseling dan Psikoterapi, Terjemahan W. Koswara, Bandung: Erosco, h. 14 
realitas atau the reality prinsiple. ${ }^{75}$ Ego bekerja secara realistis dan berfikir logis dalam merumuskan tindakan dalam memenuhi kebutuhan.

Super ego merupakan aspek sosiologis dari kepribadian manusia yang berisikan tentang nilai-nilai atau aturan-aturan yang sifatnya menyangkut baik buru, etis tidak etis, pantass tidak pantas, serta benar dan salah. Dengan demikian super ego dianggap sebagai cabang moral atau hukum keperibadian. ${ }^{76}$ uper ego prinsip kerjanya selalu sesuai dengan nilai-nilai dan norma-norma, sebab super ego berisikan dorongan untuk berbuat kebaikan dan mengikuti norma-norma dalam masyarakat. ${ }^{77}$ Berhubung tugas super ego yang kerjanya menilai baik buruknya suatu perbuatan, maka keperibadian super egodisebut sebagfai hati nurani yang selalu berhubungan dengan kehidupan sosial.

Konsep dasar pertama dalam kesehatan mental menurut teori psikoanalisan adalah motivasi. Menurut teori ini, motivassi merupakan suatu gerakan atau dorongan yang terselubung dalam $i d$. Freud menafsirkan motivas aktivitas manusia dalam bentuk naluri. Naluri terbagi dua, yaitu pertama naluri hidup atau eros. Naluri ini merupakan naluri yang mengandung dorongandorongan kelamin atau bibidodan dorongan untuk menjaga diri. Kedua, naluri mati atau tanatos, yaitu naluri perusak yang memiliki dorongan untuk menghancurkan. Menurut Freud naluri terakhir tidak begitu berpengaruh dalam mendorong manusia untuk beraktifitas, tetapi Freud lebih menekankan pada naluri hidup sebagai pendorong utama tingkah laku manusia. Oleh karena itu, menurut Freud pemuasan kelamin merupakan kekuatan utama yang mendorong manusia dalam hidupnya. ${ }^{78}$

Konsep dasar kedua dalam kesehatan mental adalah pertarungan atau conflics. Menurut aliran ini, konflik merupakan suatu pertempuran "dalam" diantara berbagai alat-alat personality. Pertarungan muncul disebabkan karena mengikuti keinginan id yang nekat untuk memuaskan dorongan-dorongan kelaminnya, sedangkan pemuasan tersebut bertentangan dengan ego dan super ego.

Kerisauan merupakan konsep dasar ketiga dalam kesehatan mental. Menurut teori psikoanalisa respon atau pengalaman emosional yang menyakitkan yang dialami oleh seseorang terhadap berbagai alat-alat "dalam" yang tunduk di bawah jaringan bebas seperti jantung, alat pernapasan dan lailain. ${ }^{79}$ Menurut Freud, manusia didorong oleh kakuatan irrasional yang ada di dalam dirinya dan didorong oleh motif-motif yang tidak disadari serta didorong

${ }^{75}$ E. Koeswara, Op. Cit., h. 34

${ }^{76}$ Gerald Cory, Op. Cit., h. 15

${ }^{77}$ Sukanto M (2000), Nafsiologi Suatu Pendekatan Alternatif atas Psikologi, Jakarta: Integrita Press, h. 13

${ }^{78}$ Hasan Langgulung, Op. Cit., h. 93

${ }^{79}$ Ibid., h. 95 
oleh kebutuhan-kebutuhan alamiah yang bersifat biologis. Bila dorongandorongan itu tidak sejalan dengan apa yang diperlukan maka akan timbul ketegangan psikis yang disertai dengan kecemasan dan ketidaksenangan. ${ }^{80}$ Atau akan muncul kerisauan disebabkan karena kegagalan ego dalam menjaga keseimbangan antara dorongan $i d$ dengan larangan super ego. ${ }^{81}$

Konsep dasar keempat dalam kesehatan mental adalah tentang hakekat manusai. Menurut psikoanalisa, manusai pada dasarnya bersifat pesimistis, mekanistik dan reduksionistik. Manusia dideterminasi oleh kekuatan-kekuatan irrasional, motof-motif yang tidak disadari, kebutuhan atau dorongan biologis atau naluriah serta oleh peristiwa-peristiwa pertama dari kehidupan. ${ }^{82}$ Pandangan ini menganggap bahwa manusia sebagai sistem energi psikis dan tingkah-lakunya dikuasai oleh energi psikis tersebut.

b. Teori Behaviorisme

Teori ini pertama kali diciptakan oleh John Watson yang memandang tingkah laku manusia melalui pandangan ilmiah. ${ }^{83}$ Disebut behaviorisme karena menampatkan tinggkah laku makhluk hidup dan gerak-gerik jasmaninya sebagai subjek ilmu jiwa atau psikologi. ${ }^{84}$ Konsep dasar pertama tentang motivasi menurut aliran behaviorisme berbeda dengan konsep dasar yang dikemukakan oleh Freud. Jika Freud memandang bahwa naluri kelamin mendorong tingkah laku manusia, maka behaviorisme menekankan motivasi manusia dengan adanya respon dari dunia eksternal, yaitu sesuatu yang datang dari luar diri manusia. ${ }^{85}$ Manusa pada dasarnya dibentu dan ditentukan oleh lingkungan sosial budayanya. Pandangan aliran behaviorisme tentang motivasi adalah sebagai berikut:

1) Tidak menyangkal adanya naluri, tetapi tidak menganggap naluri sebagai sesuatu terpenting dalam kehidupan sehari-hari.

2) Seseorang memperoleh motivasi dari pengalaman-pengalaman dan pendidikan yang dialami seseorang.

3) Tidak menyangkal adanya faktor asal yang mendorong seseorang dalam berbagai aktifitas seperti emosi, tetapi aliran behaviorisme membatasi pada perbincangan tentang faktor-faktor asal pada tiga jenis emosi, yaitu takut, marah dan gembira.

${ }^{80}$ W.S. Wingkel (1998), Bimbingan dan konseling di Institusi Pendidikan, Jakarta: Gramedia, h. 381

${ }^{81}$ Sukanto M, Op. Cit., h. 13

${ }^{82}$ Gerald Corey, Op. Cit., h. 15

${ }^{83}$ Yulianti, H. (2019). Kontribusi Agama Islam Terhadap Kesehatan Mental (Doctoral dissertation, UIN Raden Intan Lampung).

${ }^{84}$ M. Al Baqir Ash-Shadr (2011)Falsafatuna: Pandangan terbadap Pelbagai Aliran Filsafat

Dunia, Terjemahan M. Nur Mufid bin Ali, Bandung: Mizan, h.100

${ }^{85}$ Hasan Langgulung, Op. Cit., h. 103 
4) Seseorang memperoleh nilai-nilainya berdasarkan prinsip dimana ia memperoleh keterampilan-keterampilan lain.

5) Tidak menyangkal adanya aspek-aspek rohaniah yang dapat mendorong tingkah laku manusia, tetapi teori behaviorisme tidak mampu berbicara tentang itu, sehingga kajiannya lebih ilmiah dibanding pandangan Freud yang menganggap agama atau aspek rohaniah sebagai penyakit psikologis pada manusia. ${ }^{86}$

Konsep dasar kedua, tentang pertarungan. Menurut paham behaviorisme pertarungan muncul karena adanya proses pertalian bersyarat dimana pertarungan jiwa itu muncul. ${ }^{87}$ Maksudnya adalah pertarungan akan muncul apabila diajukan suatu rangsangan kepada organisme dimana rangsangan memiliki kemampuan merangsang dua respon bertentangan yang sama kuatnya.

Konsep dasar ketiga dalam kesehatan mental tentang kerisauan. Menurut paham behaviorisme, kerisauan muncul sebagai akibat dariadanyastimulus yang sepatutnya tidak perludirespon, tetapi tetap direspon oleh individu karena tidak mampu mengendalikan diri atau karena adanya pengalaman yang kurang baik. ${ }^{88}$ Dengan kata lain, faktor yang menyebabkan adanya kerisauna adalah konflik batin manusia akibat rangsangan pendidikan atau pengaruh serta pengalaman yang tidak baik.

Konsep dasar keempat tentang hakekat manusia dalam pandangan behaviorisme tidak menguraikan tentang asumsi-asumsi yang mendasar, akan tetapi menurut dibentuk dan dikendalikan oleh dunia luar. ${ }^{89}$ Selain itu manusia memiliki kecenderungan positif dan negatif sesuai dengan apa yang didapat dari lingkungannya.

c. Teori Humanisme

Teori humanisme merupakan aliran ketiga terbesar dalam psikologi yang mangkaji manusia secara universal dalam kehidupan, baik masa lampau, masa sekarang maupun masa akan datang. Teori ini muncul sebagai reaksi atau penolakan terhadap teori-teori sebelumnya. Dalam konsep dasar pertama yang berkaitan dengan motivasi atau motif. Menurut teori humanisme motif utama manusia adalah pemenuhan kebutuhan. Teori ini berpendapat, manusia bertingkah laku ditentukan oleh kebutihannya. ${ }^{90}$

${ }^{86} \mathrm{Ibid}$.

${ }^{87}$ Ibid., h. 134

${ }^{88}$ Ibid., h. 122

${ }^{89}$ Ibid., h. 127

${ }^{90}$ Sabiq, Z. (2016). Konseling Sufistik: Harmonisasi Psikologi dan Tasawuf dalam Mewujudkan Kesehatan Mental. 'Anil Islam: Jurnal Kebudayaan dan Ilmu Keislaman, 9(2), 328-352. 
Carl Rigers mengatakan bahwa kesehatan mental akan terwujud apabila terjadi equilibium antara kebutuhan jasmani dan rohani. ${ }^{91}$ Dalam teori ini Maslow memberikan sumbangan yang sangat besar dalam pengembangan aliran ini terutama dalam mengemukakan tingkatan kebutuhan manusia, yang tersusun seperti piramida yang unsur-unsurnya mencakup :

1) Physical need atau kebutuhan jasmaniah

2) Safety need atau kebutuhan rasa aman

3) Love need atau kebutuhan kasih sayang

4) Esteem need atau kebutuhan akan harga diri

5) Self need atau kebutuhan aktualisai diri. ${ }^{92}$

Konsep dasar kedua dalam kesehatan mental tentang pertarunga. Menurut aliran humanisme pertarungan timbul jika seseorang menghadapi suatu suasana yang mengandung unsur penghalang dalam mewujudkan kemanusiaan dengan sempurna. ${ }^{93}$ Dengan kata lain, pertarungan berlaku antara kemauan untuk mewujudkan diri dengan kekuatan-kekuatan yang menghambatnya. Sedangkan konsep dasar tentang kerisauan menurup aliran humanisme timbul karena adanya rasa takut akan masa depan yang mengancam wujud manusai dan kemanusaan seseorang.

\section{Keperibadian narsistik dan implikasinya terhadap kesehatan mental}

Kepribadian narsistik yang dimiliki oleh seseorang akan berimpiliasi terhadap kesehatan mental. Mental yang sehat bukan ditandai oleh kesehatan fisik. Kesehatan mental bukan hanya menekankan pada aspek kesehatan psikologis dan sosial semata, melaikan juga mencakup aspek spiritual dan agama. ${ }^{94}$ Dadang Hawari mengistilahkan dengan "emat dimensi sehat yaitu : biopsiko-sosial-spiritual". ${ }^{95}$ Ini berarti bahwa, seseorang dikatakan sehat mentalnya bukan hanya terhindar dari gangguan dan penyakit jiwa neurosis maupun psikosos, melainkan juga sangat ditentukan oleh kemampuannya dalam menyesuaikan diri terhadap dirinya maupun lingkungan sosial. ${ }^{96}$ Kesehatan mental juga sangat ditentukan oleh kemampuan individu dalam menyelesaikan masalah dan konflik batin dalam dirinya, mampu menjalin hubungan yang harmonis terhadap fungsi-fungsi kejiawaan seperti akal, pikiran, perasaan dan

${ }^{91}$ Arif Budiman dan Abu Bakar Baraja,Op. Cit.,h. 19

${ }^{92}$ Andi Mapiere. A. T (2000), Pengantar Konseling dan Psikoterapi, Jakarta: Rajawali Press, h. 85

${ }^{93}$ Hasan Langgulung, Op. Cit., h. 137

${ }^{94}$ Nurmala, I. (2020). Mewnjudkan Remaja Sehat Fisik, Mental dan Sosial:(Model Intervensi Health Educator for Youth). Airlangga University Press.

${ }^{95}$ Dadang Hawari (2001), Manajemen Stress, Cemas dan Depresi, (Jakarta: FKUI Press), h. 87

${ }^{96}$ Ayuningtyas, D., \& Rayhani, M. (2018). Analisis Situasi Kesehatan Mental Pada Masyarakat Di Indonesia Dan Strategi Penanggulangannya. Jurnal Ilmu Kesehatan Masyarakat, 9(1), 1-10. 
keinginan serta mampu memanfaatkan segala potensi untuk mendapatkan kebahagiaan hidup. ${ }^{97}$

Kesehatan mental memilikim peran yang sangat penting dalam kehidupan setiap individu. Dengan mental yang sehat, individu akan terhindar dari stres, mampu mengendalikan diri dan memiliki ketahanan terhadap berbagai tekanan, baik dari dirinya sendiri maupun lingkungan. H. Carl Witherington mengemukakan, orang yang mentalnya sehat hatinya tenteran, nyaman dan mesa aman. ${ }^{98}$ Hal ini sejalan dengan pendapat Daradjat yang menyatakan bahwa dengan mental yang sehat seseorang akan menemukan kebahagiaan dalam kehidupannya, terhindar dari penyakit hati, mampu menyesuaikan diri, mampu menyelesakan masalah dengan baik dan mampu memanfaatkan serta mengembangkan segala potensi secara optimal. ${ }^{99}$

Dalam kajian psikologi, seseorang dikatakan memiliki mental yang sehat apabila mampu mengenal dirinya, memiliki pertumbuhan dan perkembangan secara baik, memiliki mental yang seimbang, tahan terhadap tekanan, mandiri, hidur realistis, mampu berempati, mampu menyesuaikan diri secara sosial, mampu beradaptasi dengan lingkungan dan berintyeraksi secara baik. ${ }^{100}$

Dalam presfektif Islam, Ibn Rusyd dalam “asl al-Maqal” menjelaskan, takwa merupakan unsur penting untuk mewujudkan kesehatan dalam diri seseorang. ${ }^{101}$ Menurut Al-Ghazali seseorang yang sehat mentalnya merupakan gambaran dari insanul kamil atau manusia paripurna. Ciri dari insanul kampi adalah dalam beribadah motifnya semata-mata karena Allah, melakukan amal ibdah berdasarkan ilmu dan selalu menyertakan Allah dalam meneyelesaikan berbagai persoalan. ${ }^{102}$ Pendapat lain menjelaskan, mental yang sehat ditandai dengan adanya rasa cinta, cinta terhadap Sang Khalik, cinta terhadap disi sendiri dan cinta terhadap sesama. Cinta terhadap Sang Khalik akan melahirkan ketaan dan kepatuhan terhadap perintah-Nya, cinta terhadap diri sendiri akan melahirkan sikap tanggung jawab, syukur dan dan selalu berusaha untuk mengembangkan segala potensi yang dilikilinya. Cinta terhadap sesama akan melahirkan sikap kasih sayang antar sesama dan menjauhkan diri dari sikap permusuhan, dendam dan iri hati. ${ }^{103}$ Usman Najati (dalam Masganti) menjelaskan, mental yang sehat ditandai dengan adanya akhlakuk karimah,

${ }^{97}$ Fakhriyani, D. V. (2019). Kesehatan Mental (Vol. 124). Duta Media Publishing.

${ }^{98}$ Jalaluddin, Op. Cit., h. 176

${ }_{99}$ Zakiah Daradjat, Op. Cit., h. 9.

${ }^{100}$ Daradjat, Zakiah, Op. Cit., h. 99

${ }^{101}$ Dalimunthe, S. S. (2018). Ontologi Pendidikan Islam: Mengupas Hakikat Pendidikan Islam dari Konsep Khalifah, Insan Kamil, Takwa, Akblak, Ibsan, dan Khairu Al-Ummah. Deepublish.

${ }^{102}$ Rusdiana, A. (2017). Pemikiran Ahmad Tafsir tentang Manajemen Pembentuk Insan Kamil. At-Tarbawi: Jurnal Kajian Kependidikan Islam, 2(2), 97-114.

${ }^{103}$ Abdul Mujib dan Jusuf Mudzakir (2012), Nuansa-nuansa Psikologi Islam, Jakarta : PT. Raja Grafindo Persada, h. 79 
ketenangan jiwa, memiliki akidah yang kokoh, khusuk dalam beribadah dan manjauhkan diri dari perbuatan yang dilarang Allah SWT. ${ }^{104}$

Mustafa Fahmi menjelaskan, individu yang sehat mentalnya ditandai dengan adanya kemampuan untuk menerima dirinya sendiri, baik kelebihan maupun kekurangan yang dimilikinya. Selain itu, individu yang sehat mentalnya mampu bersikap dan berperilaku secara wajar, memiliki kesetabilan jiwa, emosi dan pikiran, ${ }^{105}$ Pribadi yang sehat mentaknya, akan menggunakan akal fikirannya untuk merenung, mengamati, memikirkan dan menganalisis tanda-tanda kekuasaan Allah, beriman kepada Allah dan menyeru kepada kebaikan dan mencegah segala kemungkaran. Allah berfirman tentang tabliqh dalam Q.S. Ali Imran ayat 110 yang berbunyi :

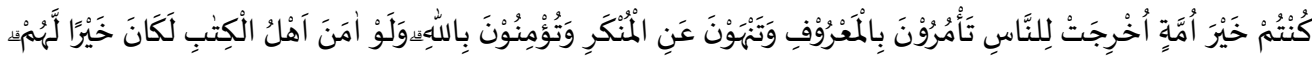

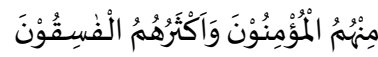

Kamu (umat Islam) adalah umat terbaik yang dilabirkan untuk manusia, (karena kamu) menyurub (berbuat) yang makruf, dan mencegah dari yang mungkar, dan beriman kepada Allah. Sekiranya Abli Kitab beriman, tentulah itu lebih baik bagi mereka. Di antara mereka ada yang beriman, namun kebanyakan mereka adalah orang-orang fasik. (QS. Ali Imran: 110)

Berdasarkan ciri-ciri kesehatan mental sebagaimana dikemukakan di atas, maka dapat dikatakan bahwa keperibadian narsistik akan berimplikasi terhadap kesehatan mental. Menatal yang sehat dalam presfektif Islam ditandai dengan adanya motif dalam melakukan semua aktifitas semata-mata karena Allah. Orang yang memiliki keperibadian narsistik, dalam melakukan sesuatu semata untuk membanggakan diri dan untuk mendapatkan pujian dari orang lain. Mental yang sehat juga ditandai oleh adanya sikap kasih sayang terhadapa sesama. Orang yang memiliki gangguan kepribadian nasrisitik, tidak mampu menjalin hubungan sosial terhadap sesama secara baik. Oleh karena itu, kepribadian narsistik jika tidak segera diatasi akan mengakibatkan kesehatan mental seseorang terganggu

\section{PENUTUP}

Gangguan kepribadian narsistik pada dasarnya adalah gangguan kepribadian yang disebabkan adanya sikap atau perilaku seseorang yang berlebihan dalam memandang dirinya sendiri. Akibatnya timbul cinta dan fantasi yang berlebihan terhadap kelebihan dan keunikan yang dimilikinya. Ada beberapa ciri seseorang memiliki gangguan kepribadian narsistik, diantaranya adalah suka mengagungkan diri sendiri, selalau inging mendapatkan pujian dan

104 Masganti (2011), Psikologi Agama,Medan : Pedana Publishing, h. 165.

105 Musthafa Fahmi (1997), Kesehatan Jiwa dalam Keluarga, Sekolah dan Masyarakat, Jilid 1, Alih Bahasa, Zakiah Daradjat, Jakarta: Bulan Bintang, h. 20-22. 
perhatian, ingin mendapatkan perlakuan spesial, mmeiliki khayalan yang berlebihan tentang perhatian dari orang lain, kurang memiliki empati terhadp orang lain, sering stres dalam menghadapi masalah dan tidak besa menerima kritik. Narisistik dapat mengakibatkan gangguan kesehatan mental, jika sikap dan perilaku narsistik tersebut sudah menganggu fungsi-fungsi kehidupan, seperti perasaan, hubungan sosial, pekerjaan dan sebagainya. Sikap dan perilaku narsistik yang belum kronis dapat diatasi dengan beberapa cara diantaranya adalah dengan melatih diri memandang orang lain secara positif, bersikap dan berperilaku secara sederhana, melatih diri untuk berempati, bersikap rendah hati dan melakukan evaluasi terhadap sikap serta perilaku dalam kehidupan seharihari.

\section{DAFTAR PUSTAKA}

Abdul Mujib dan Jusuf Mudzakir (2012), Nuansa-nuansa Psikologi Islam, Jakarta : PT. Raja Grafindo Persada.

Abadi, T. W., Sukmawan, F., \& Utari, D. A. (2016). Media sosial dan pengembangan hubungan interpersonal remaja di Sidoarjo. KANAL: Jurnal Ilmu Komunikasi, 2(1), 95-106.

Andi Mapiere. A. T (2000), Pengantar Konseling dan Psikoterapi, Jakarta: Rajawali Press

Arif Budiman dan Abu Bakar Baradja (1999), Mental Sehat Hidup Nikmat, Mental Sakit Hidup Pahit,Jakarta: Studi Press.

Asrori, A. (2016). Terapi kognitif perilaku untuk mengatasi gangguan kecemasan sosial. Jurnal Ilmiah Psikologi Terapan, 3(1), 89-107.

Atkinson, Rita L., (1991), Pengantar Psikologi Jilid 2, Batam : Ineraksa.

Ayuningtyas, D., \& Rayhani, M. (2018). Analisis Situasi Kesehatan Mental Pada Masyarakat Di Indonesia Dan Strategi Penanggulangannya. Jurnal Ilmu Kesehatan Masyarakat, 9(1), 1-10.

Azizurahman, M. A. M., \& Purnama, H. (2017). Representasi Narsisme dalam Iklan Sprite (analisis Semiotika Charles Sanders Peirce Pada Iklan Youtube Sprite Versi Kenyataan Gak Seindah Sosmed Selebriti-\# ootd). eProceedings of Management, 4(3).

Cahyono, A. S. (2016). Pengaruh media sosial terhadap perubahan sosial masyarakat di Indonesia. Jurnal Publiciana, 9(1), 140-157.

Dadang Hawari (2001), Manajemen Stress, Cemas dan Depresi, Jakarta: FKUI Press. 
Dalimunthe, S. S. (2018). Ontologi Pendidikan Islam: Mengupas Hakikat Pendidikan Islam dari Konsep Khalifah, Insan Kamil, Takwa, Akblak, Ihsan, dan Khairu AlUmmah. Deepublish.

Davidson, Gerald C., (2010), Psikologi Abnormal, Jakarta : Rajagrafindo Persada.

Djamaludin Ancok, (2011), Psikologi Islami Solusi Islam atas Problem-problem Psikologi, Yokyakarta : Pustaka Pelajar

E. Keswara (19997), Teori-teori Keperibadian, Bandung: Erosco

Engkus, E. (2016). Perilaku narsis di kalangan remaja pelajar pada media sosial dan upaya penanggunglangannya (penelitian terhadap ramaja pelajar di kawasan Bandung Timur). lib. ninsgd. ac. id, 1-150.

Engkus, E., Hikmat, H., \& Saminnurahmat, K. (2017). Perilaku narsis pada media sosial di kalangan remaja dan upaya penanggulangannya. Jurnal Penelitian Komunikasi, 20(2).

Fakhriyani, D. V. (2019). Kesehatan Mental (Vol. 124). Duta Media Publishing.

Fausiah \& Widury, J (2005), Psikologi Abnormal: Klinis Dewasa, Jakarta : Universitas Indonesia

Gerald Corey (1999), Tori dan Praktek Konseling dan Psikoterapi, Terjemahan W. Koswara, Bandung: Erosco.

Hamid, A. (2017). Agama dan kesehatan mental dalam perspektif psikologi agama. Healtby Tadulako Journal (Jurnal Kesehatan Tadulako), 3(1), 1-14.

Haryanto, H., Wahyuni, H. D., \& Nandiroh, S. (2016). Sistem Deteksi Gangguan Depresi Pada Anak-anak dan Remaja. Jurnal Ilmiah Teknik Industri, 14(2), 142-152.

Hasan Langgulung (2000), Teori-teori Kesehatan Mental, Jakarta: al Husna.

Haya Binti Mubarok Al-Barik (1418 H), Ensiklopedi Wanita Muslimah, Jakarta : Darul Falah.

Hendrata, N. D., \& Christianto, L. P. (2017). Keterkaitan Minat Selfie Dengan Kepribadian Narsistik dan Harga Diri Pada Remaja.

Hidayah, N., \& Huriati, H. (2017). Krisis identitas diri pada remaja "identity crisis of adolescences". Sulesana: Jurnal Wawasan Keislaman, 10(1), 49-62.

Holilah, I. (2017). Dampak Media Terhadap Perilaku Masyarakat. Jurnal Studi Gender dan Anak, 3(01), 103-114.

Husni, M. (2019). Selfie Gangguan Kepribadian Narsistik. Jurnal Tinta, 1(1), $105-$ 116.

Imam Abu Syaikh, (2011), Meneladani Akblak Nabi, Jakarta : QitshiPress. 
Insani, C. Kajian psikologi komunikasi pada fenomena selfie remaja di facebook. Relasi negara industri dan masyarakat dalam perspektif komunikasi, 217.

Izzati, F., \& Irma, A. (2018). Perilaku Narcissistic Pada Pengguna Instagram Di Kalangan Mahasiswa Universitas Serambi Mekkah. Jurnal Ilmiah Mahasiswa Fakultas Ilmu Sosial \& Ilmu Politik, 3(2).

James and Butcher, Susan Mineka, Jill M (2008), Abnormal Psychology Core Concept, Hooley: Pearson Educational USA.

Jazilah, N. (2017). Hubungan Antara Kesepian Dengan Ciri-Ciri Narsistik Pada Pelaku Selfie Di Media Sosial. Naskah Publikasi Prodi Psikologi.

Kartini Kartono (19998), Mental Hygiene (Kesehatan Mental), Bandung: Alumni, Cet. Ke 5

Khatibah, K. (2011). Penelitian kepustakaan. Iqra': Jurnal Perpustakaan dan Informasi, 5(01), 36-39.

Komarudin Hidayat (1998), Agama Masa Depan: Presfektif Filsafat Parennial, Jakarta: Pramadina.

M. Al Baqir Ash-Shadr (2011) Falsafatuna: Pandangan terhadap Pelbagai Aliran Filsafat Dunia, Terjemahan M. Nur Mufid bin Ali, Bandung: Mizan.

Mansir, F. (2018). Pendekatan Psikologi dalam Kajian Pendidikan Islam. Psikis: Jurnal Psikologi Islami, 4(1), 61-73.

Masganti (2011), Psikologi Agama, Medan : Pedana Publishing.

Musthafa Fahmi (1997), Kesehatan Jiwa dalam Keluarga, Sekolah dan Masyarakat, Jilid 1, Alih Bahasa, Zakiah Daradjat, Jakarta: Bulan Bintang.

Najamuddin, N., Negara, H. R. P., Ramdhani, D., \& Nurman, M. (2019). Sosial Media Dan Prestasi Belajar: Studi Hubungan Penggunaan Facebook Terhadap Prestasi Belajar Siswa. Jurnal Tatsqif, 17(1), 70-86.

Nurmala, I. (2020). Mennijudkan Remaja Sehat Fisik, Mental dan Sosial:(Model Intervensi Health Educator for Youth). Airlangga University Press.

Nurmalasari, Y. (2016). Konseling Singkat Berfokus Solusi dalam Mengembangkan Kemampuan Mengendalikan Compulsive Internet Use Siswa. EMPATI-Jurnal Bimbingan dan Konseling, 3(2).

Quraish Shihab (2007), Tafsir Al-Misbah Vol. 2, Jakarta : Lentera Hati.

Rachman, A. (2017). Pemanfaatan media sosial bagi penciptaan, pemeliharaan dan penyebarluasan pengetahuan dan keterampilan kearifan lokal di afrika timur. ORASI: Jurnal Dakwah dan Komunikasi, 6(1). 
Rahman, T. G., \& Ilyas, A. (2019). Perilaku Narsistik Pengguna Media Sosial di Kalangan Mahasiswa dan Implikasi dalam Layanan Bimbingan Dan Konseling. E-Journal Pembelajaran Inovasi, Jurnal Ilmiab Pendidikan Dasar, 7(4), 1-8.

Robert. W. Crapps (1997), Dialog Psikologi dan Agama Sejak. William james bingga Gordont. W. Allpot, Terjemahan Harjana, Yogyakarta: Kanisus.

Rosleni Marliany (2015), Psikologi Islam, Bandung : Pustaka Setia.

Rusdiana, A. (2017). Pemikiran Ahmad Tafsir tentang Manajemen Pembentuk Insan Kamil. At-Tarbawi: Jurnal Kajian Kependidikan Islam, 2(2), 97-114.

Sabiq, Z. (2016). Konseling Sufistik: Harmonisasi Psikologi dan Tasawuf dalam Mewujudkan Kesehatan Mental. 'Anil Islam: Jurnal Kebudayaan dan Ilmu Keislaman, 9(2), 328-352.

Sahri, M. A. (2021). Mutiara Akblak Tasamuf. PT. RajaGrafindo Persada.

Sakinah, U., Zatrahadi, M. F., \& Darmawati, D. (2019). Fenomena Narsistik di Media Sosial Sebagai Bentuk Pengakuan Diri. Al-Ittizaan: Jurnal Bimbingan Konseling Islam, 2(1), 34-43.

Saleh, G., \& Muzammil, M. Pengaruh media sosial instagram dalam perilaku narsis pada pelajar SMA di kota Pekanbaru. Jurnal Ilmu Komunikasi, 8(4).

Santi, N. N. (2017). Dampak kecenderungan narsiscisme terhadap self esteem pada pengguna facebook mahasiswa PGSD UNP. Jurnal Dimensi Pendidikan dan Pembelajaran, 5(1), 25-30.

Sigmund Freud (1993), Sekelumit Sejarah Psikologianalisa, Terjemahan K. Bertens, Jakarta: Gramedia.

Suhartanti, L. (2016). Pengaruh kontrol diri terhadap narcissistic personality disorder pada pengguna Instagram di SMA N 1 Seyegan. E-Journal Bimbingan dan Konseling, 8(5), 184-195.

Sukanto M (2000), Nafsiologi Suatu Pendekatan Alternatif atas Psikologi, Jakarta: Integrita Press.

Sumadi Suryabrata 2008), Psikologi Keperibadian, Jakarta: Rajawali Press.

Syam, E., Fauzi, M., \& Syamsidari, R. (2017). Narsisisme dan kompleks oedipus yang tergambar dalam Pygmalion, karya George, Bernard Shaw: Kajian Psikoanalisis . Jurnal Pustaka Budaya, 4(2), 58-82.

Syamsu Yusuf (2004), Mental Hygiene Pengembangan Kesehatan Mental Dalam Kajian Psikologi dan Agama, Bandung: Pustaka Bani Quraisy.

Triwahyuni, A., Purwono, U., Sadarjoen, S. S., \& Sapri, E. R. (2019). Pengembangan Millon Personality Type Inventory (MPTI) sebagai 
Instrumen Pengukuran Kepribadian di Indonesia. Journal of Psychological Science and Profession, 3(2), 65-74.

W.S. Wingkel (1998), Bimbingan dan konseling di Institusi Pendidikan, Jakarta: Gramedia.

Widiyanti, W., Solehuddin, M., \& Saomah, A. (2017). Profil perilaku narsisme remaja serta implikasinya bagi bimbingan dan konseling. Indonesian Journal of Educational Counseling, 1(1), 15-26.

Widiyanti, E., \& Herwandito, S. (2018). Identitas diri dan hiperealitas dalam media sosial. Cakrawala, 7(2), 231-250.

Yahya Jaya (1999), Peranan Taubat dan Maaf dalam Kesehatan Mental, Jakarta: Ruhama.

Yulianti, H. (2019). Kontribusi Agama Islam Terbadap Kesehatan Mental (Doctoral dissertation, UIN Raden Intan Lampung).

Zahnia, S., \& Sumekar, D. W. (2016). Kajian epidemiologis skizofrenia. Jurnal Majority, 5(4), 160-166.

Zakia Daradjat (2012), Islam dan Kesehatan Mental, Jakarta: PT. Gunung Agung.

Zed, M. (2004). Metode peneletian kepustakaan. Yayasan Obor Indonesia 